\title{
CONCEPÇÃO, IMPLEMENTAÇÃO E ANÁLISE DE UM DISPOSITIVO DE ACOMPANHAMENTO DE ESTAGIÁRIOS COMO PARTE DE UMA PESQUISA COLABORATIVA
}

\author{
MARINA CYRINO ${ }^{1}$ \\ ORCID: https://orcid.org/0000-0001-6286-8719 \\ SAMUEL DE SOUZA NETO ${ }^{2}$ \\ ORCID: https://orcid.org/0000-0002-8991-7039 \\ FLAVIA MEDEIROS SARTI \\ ORCID: https://orcid.org/0000-0003-2926-5873
}

\begin{abstract}
RESUMO: O artigo apresenta resultados de uma pesquisa colaborativa que objetivou a elaboração e a análise de dispositivos voltados ao acompanhamento conjunto (envolvendo instituição de ensino superior e escola) do estágio supervisionado de prática de ensino em um curso de Pedagogia. A investigação envolveu diferentes atores ligados ao estágio, totalizando 43 participantes envolvidos, distribuídos nas seguintes categorias: professores atuantes nos anos iniciais do ensino fundamental (denominados professores-parceiros), coordenadores pedagógicos, diretor e vice-diretor de escola, estagiários e uma professora universitária supervisora de estágio. Por meio de estudo documental, observações do processo formativo e de grupos focais realizados com os participantes, foram elaborados dois dispositivos de acompanhamento voltados à reflexão e análise de práticas de ensino: um dispositivo direcionado aos estagiários e outro aos professores-parceiros. Os dispositivos foram analisados com base no modelo de Albero (2010), que segue três dimensões: ideal, operacional e vivida. Concluímos que os dispositivos implementados no estágio contribuíram de forma significativa para sua organização e para o acompanhamento dos estagiários, valorizando o papel do professor da escola no processo formativo e favorecendo a produção de disposições docentes por parte dos estagiários. Os limites encontrados no emprego dos dispositivos dizem respeito ao desenvolvimento da reflexão e da análise de práticas por parte dos estagiários.
\end{abstract}

Palavras-chave: estágio curricular, licenciatura em Pedagogia, dispositivos de formação, formação inicial de professores.

\footnotetext{
${ }^{1}$ DOFPPEN (Grupo de Pesquisa Docência, Formação de Professores e Prática de Ensino - Unesp/Rio Claro. São Paulo, SP, Brasil.<ma.cyrino@hotmail.com>

${ }^{2}$ Universidade Estadual Paulista Júlio de Mesquita Filho (Unesp), Rio Claro - Departamento de Educação. São Paulo, SP, Brasil.<Samuel.souza-neto@unesp.br>

${ }^{3}$ Universidade Estadual Paulista Júlio de Mesquita Filho (Unesp), Rio Claro - Departamento de Educação. São Paulo, SP, Brasil.<flavia.sarti@unesp.br>
} 


\title{
CONCEPTION, IMPLEMENTATION, AND ANALYSIS OF A SUPPORT DEVICE FOR PRE-SERVICE TEACHER TRAINING AS PART OF A COLLABORATIVE RESEARCH
}

\begin{abstract}
The article presents the results of a collaborative research that aimed to create and analyze devices used on the joined support (involving the university and school) of supervised preservice teacher training of Pedagogy students. The research involved different actors of the training, in a total of 43 participant, including the following categories: elementary teachers (called partner teachers), pedagogical coordinators, school principal and vice-principal, in-training undergraduate students, and the professor in charge of the training. Through the analysis of documents, observation of the training process, and focal groups with participants, we created two support devices to trainees and partner teachers. The devices were analyzed based on the model of Albero (2010) which follows three dimensions: ideal; operational; and experienced. We concluded that the devices implemented during training significantly contributed to its organization and the support of trainees, valuing the role of the schoolteacher in the training process, and favoring the creation of teaching dispositions in trainees. The limits found on the use of the devices refer to the development of reflection and the analysis of the practices by the trainees.
\end{abstract}

Key words: Supervised training; Pedagogy; Training devices; Pre-service teacher training

\section{CONCEPCIÓN, IMPLEMENTACIÓN Y ANÁLISIS DE UN DISPOSITIVO DE ACOMPAÑAMIENTO DE PASANTES COMO PARTE DE UNA INVESTIGACIÓN COLABORATIVA}

RESÚMEN: El artículo presenta los resultados de una investigación colaborativa que tuvo como objetivo elaborar y analizar dispositivos para el acompañamiento conjunto (que involucran la institución de educación superior y la escuela) de la pasantía supervisada de práctica docente en un curso de pedagogía. La investigación involucró a diferentes actores vinculados a la pasantía, totalizando 43 participantes: maestros que trabajan en la escuela primaria (llamados maestros asociados), coordinadores pedagógicos, directores de la escuela, pasantes y una maestra universitaria que supervisa las pasantías. A través del estudio documental, observaciones y grupos focales realizados con los participantes, se elaboraron dos dispositivos de acompañamiento para reflejar y analizar las prácticas de enseñanza: un dispositivo dirigido a los pasantes y otro a los maestros asociados. Los dispositivos se analizaron según el modelo de Albero (2010) que sigue tres dimensiones: ideal; operacional; y vivida. Concluimos que los dispositivos implementados en la pasantía contribuyeron significativamente a su organización y al acompañamiento de los pasantes, valorando el papel del maestro de la escuela en el proceso de formación y favoreciendo la producción de disposiciones docentes por pasantes. Los límites encontrados en el uso de dispositivos se refieren al desarrollo de la reflexión y del análisis de la práctica por parte de los pasantes.

Palabras clave: pasantía; licenciatura en pedagogía; dispositivos de formación; formación inicial del profesorado.

\section{INTRODUÇÃO}

O debate sobre a formação de professores no Brasil tem estabelecido crescente relação com o movimento internacional de profissionalização do ensino que, entre outros fatores, estimulou a elevação ao nível superior da formação requerida para nossos professores que atuam nos anos iniciais do ensino fundamental. Tal elevação, proposta pela Lei de Diretrizes e Bases (BRASIL, 1996), contribuiu para a diminuição do número de professores da Educação Básica sem ensino superior, comparando-se os anos de 2009 (52\% na educação infantil e 38,7\% nos anos iniciais) e 2016 (34\% na educação infantil e 25\% nos anos iniciais) (GATTI et al., 2019). No que diz respeito especificamente 
aos professores que atuam nos anos iniciais da Educação Básica, 79,3\% possuem curso superior, e na Educação Infantil o percentual é de 70\% (INEP, 2018).

No atendimento a essa demanda formativa, as instituições de ensino superior (IES) vêm enfrentando desafios já conhecidos, impostos às demais licenciaturas, referentes às articulações entre teoria e prática, bem como aos vínculos que estabelecem com o magistério, na condição de grupo ocupacional, e com as escolas. Falta-lhes uma "cultura profissional de formação docente" (VASQUES, 2019). Premissas voltadas à necessidade de maior colaboração entre IES e escolas na formação de professores têm sido amplamente discutidas na literatura da área, como caminho a ser seguido para profissionalizar o ofício docente (NÓVOA, 1992; 2011; MARCELO, 1999; MICHAUD, 1999; TARDIF, 2002).

No que se refere mais especificamente ao estágio supervisionado, tais expectativas relativas à colaboração IES-escola têm se articulado a outras, referentes à consideração da escola como lócus privilegiado de formação docente (BRASIL, 2001; VILLENEUVE; MOREAU, 2010; NÓVOA, 2011; ALMEIDA; PIMENTA, 2014). Nessa direção, espera-se que instituições de ensino superior e escolas colaborem para oferecer aos estagiários "um contexto de aprendizagem no qual a ação está a serviço da reflexão, e a reflexão a serviço da ação" (VILLENEUVE; MOREAU, 2010, p. 445, tradução nossa). Tal encaminhamento "não pode se fazer sem acompanhamento. Para isso, as duas instituições devem contribuir" do início ao fim do estágio (VILLENEUVE; MOREAU, 2010, p. 445, tradução nossa). Essas demandas de colaboração em torno do estágio constituem o ponto principal da investigação aqui apresentada.

Partimos do pressuposto de que o estágio concebido e realizado por meio de um acompanhamento compartilhado entre IES e escolas, que envolva supervisores da primeira, professores de educação básica e equipe coordenadora das escolas que recebem estagiários, poderá contribuir para a superação de limites importantes que se impõem ao modelo formativo vigente entre nós, pautado, entre outros aspectos, na mera imitação de modelos docentes, na experimentação aleatória de posturas e atividades (tentativa-erro) e na individualização das práticas (PIMENTA; LIMA, 2011).

Seguindo a dimensão antropológica proposta por Vial e Caparros-Mencacci (2007), entendemos o acompanhamento como recurso de integração do acompanhado a certa cultura, que lhe permite acessar o universal a partir de seu lugar singular. No que se refere à formação de professores, consideramos que o acompanhamento de estagiários por parte de profissionais ligados ao magistério assume destacado "teor iniciático" (SARTI, 2013, p. 96). E, tendo em vista evitar fragmentações relativas aos saberes aos quais os futuros professores estão sendo iniciados, as práticas de acompanhamento que digam respeito ao estágio devem envolver equipes pluricategoriais (TARDIF, 2000) que reúnam diferentes profissionais ligados ao ensino.

Diante de tal pressuposto, o trabalho realizado objetivou a elaboração, em colaboração, e a análise de dispositivos voltados ao acompanhamento conjunto - envolvendo IES e escola - do estágio supervisionado de prática de ensino em um curso de Pedagogia. A produção de tais dispositivos de formação se orientou pela perspectiva da análise de práticas (ALTET, 2000), seguindo a reflexão crítica sobre a prática (SMYTH, 1991).

\section{A Reflexão e a Análise de Práticas}

A profissionalização do ensino requer, entre outros aspectos, que os professores mobilizem um conjunto de conhecimentos especializados e sistematizados. Nessa mesma direção, a formação docente deve aproximar-se do trabalho dos professores, assumindo uma perspectiva clínica (PERRENOUD, 1994; PAQUAY et al., 2001) voltada para a reflexão. Trata-se de reconhecer a docência como atividade complexa, que impõe mudanças para o modelo de formação vigente, ancorado em uma racionalidade técnica (GOMEZ, 1992). Como ressalta Altet (2000, p. 33, tradução nossa):

Para os professores e formadores de professores que exercem um ofício complexo, "uma práxis" em situações sempre singulares, com públicos particulares, a formação profissional não 
pode se resumir à aprendizagem de técnicas à aplicar ou reproduzir como em um ofício de técnico.

Sob tal perspectiva, as práticas pedagógicas assumem estatuto epistemológico (PIMENTA, 1997), deixando de figurar somente como espaço de investigação e de pretensa aplicação de saberes produzidos a partir de seu exterior (pela história, psicologia etc.). As práticas passam, então, a "produzir sua própria teorização" (CHARTIER, 2007, p. 187) e tornam-se objeto de análises empreendidas com propósitos profissionais, voltadas para a explicitação de saberes dos professores. De acordo com Altet (2000), a análise de práticas prevê duas fases principais. A primeira corresponde ao momento de observação sistemática e descrição dos fatos observados, prevendo um distanciamento da situação. Essa fase tem como proposta identificar os elementos isolados, que podem ser desconstruídos. A segunda fase corresponde à análise propriamente dita, estabelecendo relação entre os elementos evidenciados na ação. Nesse exercício, destacam-se as diferentes variáveis pedagógicas, didáticas, psicológicas e pessoais constitutivas da prática, possibilitando que se interpretem os sentidos da ação por meio da análise compreensiva.

Especificamente, no contexto da formação inicial de professores, a análise de práticas visa "sensibilizar os futuros profissionais aos processos em jogo nas situações de interação que serão aquelas que exercerão, situações que eles podem já ter conhecido durante os estágios” (FABLET, 2004, p. 112, tradução nossa). Auxilia, portanto, o estagiário a reconhecer e refletir sobre aspectos do trabalho docente ainda em situação de formação inicial.

Desenvolve-se, assim, a prática reflexiva (PERRENOUD, 2001a; 2004), que, no contexto da análise de práticas, é reconhecida como um elemento importante, bem como é "uma abordagem estratégica para acompanhar a construção da identidade profissional docente e seu desenvolvimento" (ALTET, 2000, p. 40, tradução nossa), sendo "um verdadeiro questionamento sobre o sentido da ação, realizado coletivamente" (Idem, p. 28, tradução nossa). Nesse contexto, a análise de práticas ganha centralidade na profissionalização dos práticos pela formação inicial e continuada (FABLET, 2004).

Para desenvolver tal abordagem, são utilizados diversos instrumentos e dispositivos (ALTET, 2000) que atendem às especificidades impostas pelos objetivos traçados pelos participantes envolvidos e pela situação que se configura.

\section{Dispositivos de Formação}

A noção de dispositivo foi empregada inicialmente na literatura francófona sobre formação de professores por volta dos anos 1980. Possuindo uma dimensão intencional, o dispositivo leva em consideração as ações humanas individuais, colocando o sujeito como ator da própria formação, articulando de maneira coerente os motivos individuais dos sujeitos e suas intenções cognitivas (PEETERS; CHARLIER, 1999). Dessa maneira, os dispositivos podem auxiliar na tomada de consciência do sujeito sobre suas ações (PERRENOUD, 2001).

Essa ideia foi difundida em diversos países, dentre os quais o Brasil, onde passou a ser concebida como "processos criadores de investigação, explicação, interpretação e intervenção na realidade" (GATTI et al., 2019, p. 187). O dispositivo é, portanto, considerado "como espaço que possibilita a experiência mobilizadora de saberes, representações instituídas e outras formas criativas de pensar as relações e a formação, de pensar outras formas de vida” (OLIVEIRA, 2011, p. 187).

O sentido aqui assumido para a noção de dispositivo "engloba os locais, métodos e um conjunto funcional de atores e meios mobilizados com vistas a um objetivo" (ALBERO, 2010, p. 48, tradução nossa). Nesse sentido, os dispositivos de formação são empregados em diferentes contextos, por diferentes atores, tendo em vista o favorecimento da aprendizagem de estudantes ou de trabalhadores de diversas áreas do conhecimento por meio de três possíveis intenções que podem, mesmo com a predominância de uma delas, se sobrepor, sem necessariamente se excluir (MARCEL et al., 2002): a produção de saberes, a profissionalização, ou a evolução das práticas. No caso da escola, por exemplo, o professor, através dos dispositivos de ensino, "tenta prever e demarcar o percurso de 
formação que propôs aos seus estudantes, sob influência de suas escolhas didáticas ou pedagógicas" (WEISSER, 2010, p. 292, tradução nossa). O dispositivo, portanto, oferece maior flexibilidade, aproximando-se das realidades encontradas pelos atores em sua prática (ALBERO, 2010).

No caso de dispositivos especificamente voltados à formação profissional, correspondem artefatos funcionais que materializam "uma organização particular de objetos, de atores, de estruturas e de sistemas de relação, em função dos objetivos de formação em uma situação dada" (ALBERO, 2010, p. 50, tradução nossa). Nesse caso, o dispositivo caracteriza-se como um recurso de formação que reúne condições "para que o sujeito possa operar um retorno reflexivo sobre sua prática profissional" (FAINGOLD, 2006, p. 90, tradução nossa), e compreender o que ocorre na "complexidade das situações difíceis e momentos de sucesso" (FAINGOLD, 2006, p. 90, tradução nossa). Possibilita então, pela análise de práticas, um movimento de descentralização e de processos de tomada de consciência (FAINGOLD, 2006, tradução nossa).

No que se refere à formação de professores, os dispositivos de formação docente voltados para a formação reflexiva passam a ser previstos a partir dos anos 1990 (TARDIF; BORGES; MALO, 2012), incluindo portfólio, análise de práticas, jornal de bordo, entrevistas sobre as práticas, raciocínio prático, dentre outros. Cabe destacar, no entanto, como fazem Levain e Minary (2010), que a análise de práticas como recurso de formação docente requer urgência na criação de dispositivos específicos, movimentando o campo da educação para a profissionalização do ensino (LEVAIN; MINARY, 2010).

É nesse sentido da produção de dispositivos mais específicos que possibilitem uma formação inicial docente, pautada na análise de práticas e no acompanhamento partilhado (entre escola e IES) de estagiários, que foi proposto o trabalho aqui apresentado, cujos detalhes, do ponto de vista metodológico, serão expostos a seguir.

\section{METODOLOGIA}

A investigação aqui referida assumiu uma perspectiva qualitativa, mais especificamente a abordagem construtivo-colaborativa (COLE; KNOWLES, 1993; REALI; TANCREDI; MIZUKAMI, 2008). Reali, Tancredi e Mizukami (2008) explicam que,

\footnotetext{
Segundo essa perspectiva, há necessidade de se estabelecer com as escolas um trabalho processual, que se defina como uma via de mão dupla, evitando encará-las apenas como fornecedoras de dados para a atividade de pesquisa. Em linhas gerais, isso significa conceber que as partes envolvidas assumem papéis de natureza colaborativa [...] (p. 80).
}

Nesse sentido, as escolas e os participantes de nossa investigação foram considerados parceiros, colaborando com a produção e o desenvolvimento dos dados, ao mesmo tempo que se utilizaram destes indiretamente para sua formação.

Para a coleta de dados, foi utilizada como técnica a observação participante sobre o processo formativo, o grupo focal e a fonte documental. Na observação das atividades relativas ao estágio, buscou-se "identificar e descrever diversos tipos de interações e processos humanos" (VIANNA, 2007, p. 12) ocorridos durante o processo de formação. Com o grupo focal, realizado com professores-parceiros, coordenadores, diretor e vice-diretor e estagiários, o objetivo foi recolher informações e compreender como as pessoas pensam ou se sentem sobre uma questão (KRUEGER; CASEY, 2009), no caso, a organização e estruturação do estágio, cabendo salientar que podem ser formados por grandes grupos, entre oito a dez pessoas, ou por minigrupos de quatro a seis sujeitos ${ }^{4}$, mas sempre tendo um pesquisador como moderador, podendo a discussão ir de 60 a 120 minutos (GREENBAUM, 1998). Por fim, a fonte documental, que representa "uma fonte 'natural' de informação" (LÜDKE; ANDRÉ, 1986, p. 39), envolvendo documentos organizacionais institucionais

\footnotetext{
${ }^{4}$ Grupos focais - em função da dificuldade de uma agenda comum com todos os participantes de cada escola para o momento do grupo focal, nós mantivemos a mesma identificação para os grupos que se encontram com um número de participantes abaixo da prescrição convencional.

Educação em Revista|Belo Horizonte|v.36|e228755|2020
} 
do estágio, bem como alguns relatórios produzidos pelos estudantes (que não são objeto de análise neste artigo), o que nos forneceu dados sobre o contexto em que se fazem presentes.

A pesquisa foi desenvolvida entre os anos de 2013 e 2015, tendo como referencial empírico o curso de Pedagogia da Unesp, campus Rio Claro, na disciplina de "Estágio Supervisionado de Prática de Ensino nos Anos Iniciais do Ensino Fundamental", oferecida aos estudantes no quinto semestre do curso, com carga horária de 105 horas. O estágio naquele curso ocorre em concomitância com a disciplina "Planejamento, Acompanhamento e Noções Teóricas de Prática de Ensino nos Anos Iniciais do Ensino Fundamental", oferecida no período noturno, com carga horária de 45 horas, sendo um espaço de orientações aos estagiários no que tange ao planejamento e à organização do estágio.

A proposta da professora supervisora (professora universitária responsável por ambas as disciplinas) é de que os estudantes realizem, no estágio, uma parceria docente com os professores que os recebem em suas classes. Por meio de dispositivos de formação, espera-se que o professor-parceiro, a supervisora e o estagiário realizem o acompanhamento do processo de aprendizagem da docência.

Tivemos como participantes ${ }^{5}$ da pesquisa os diversos atores implicados no processo de estágio: alguns dos professores-parceiros, os coordenadores e diretores ${ }^{6}$ das seis escolas municipais de educação fundamental envolvidas, os estagiários e a professora supervisora da universidade, totalizando 43 pessoas que assinaram o Termo de Consentimento Livre e Esclarecido do Comitê de Ética.

Quadro 1 - Distribuição dos participantes por etapa da pesquisa.

\begin{tabular}{|c|c|c|c|c|}
\hline Escolas & $\begin{array}{l}\text { Participantes } \\
\text { Etapa } 1 \text { (2013) }\end{array}$ & $\begin{array}{l}\text { Participantes } \\
\text { Etapa } 2 \text { (2014) }\end{array}$ & $\begin{array}{c}\text { Participantes } \\
\text { Etapa } 3(2015)\end{array}$ & Total $^{7}$ \\
\hline \multirow{5}{*}{ Escola A } & CA & & P3-A & \multirow{5}{*}{8} \\
\hline & PA-1 & & P4-A & \\
\hline & PA-2 & & P5-A & \\
\hline & & & P6-A & \\
\hline & & & P7-A & \\
\hline \multirow{5}{*}{ Escola B } & CB-1 & $C B-1$ & PB-2 & \multirow{5}{*}{10} \\
\hline & CB-2 & $P B-2$ & $P B-5$ & \\
\hline & PB-1 & PB-3 & PB-6 & \\
\hline & PB-2 & PB-4 & PB-7 & \\
\hline & & PB-5 & PB-8 & \\
\hline \multirow{4}{*}{ Escola F } & DF & & PF-1 & \multirow{4}{*}{6} \\
\hline & PF-1 & & PF-4 & \\
\hline & PF-2 & & PF-5 & \\
\hline & PF-3 & & & \\
\hline \multirow{2}{*}{ Escola G } & & PG-18 & PG-3 & \multirow{2}{*}{4} \\
\hline & & PG-2 & PG-4 & \\
\hline Escola $K^{9}$ & & & & - \\
\hline \multirow{2}{*}{ Escola L } & & & PL-1 & \multirow{2}{*}{4} \\
\hline & & & PL-2 & \\
\hline
\end{tabular}

\footnotetext{
5 Os participantes estão identificados com a letra correspondente ao segmento que ocupam (Professor, Coordenador, Diretor), a letra da escola a que pertencem e um número. Exemplo: PA-1 (Professor 1 da Escola A); CA-1 (Coordenador 1 da Escola A). Os estagiários estão identificados com a letra E seguida de um número aleatório. Exemplo: E-1 (Estagiário 1). ${ }^{6}$ Coordenadores, Diretores e Vice-Diretores fizeram parte da pesquisa e foram participantes dos grupos focais juntamente com os professores das respectivas escolas; porém, nos trechos selecionados para este trabalho, não há os relatos desses atores.

${ }^{7}$ Este total corresponde ao número real de participantes, contando apenas uma vez os participantes marcados em itálico, pois estiveram presentes em mais de uma etapa (CB-1; PB-2; PB-5 e PF-1).

${ }^{8}$ Esta Coordenadora foi participante como professora na Etapa 2.

9 A Escola K sempre foi contatada, a coordenadora recebeu-nos pessoalmente em todos os momentos. Tentamos por diversas vezes marcar os grupos focais, mas os horários não eram compatíveis. Tanto na primeira como na terceira etapa, a pesquisadora conversou informalmente com o grupo de professoras que receberam os estagiários. Foi feito um registro de campo sobre esses momentos, porém o tempo e o espaço não foram adequados para a gravação das discussões, impossibilitando caracterizá-las como grupos focais. 


\begin{tabular}{|c|c|c|c|c|}
\hline & & & PL-3 & \\
\hline & & & CL & \\
\hline \multirow{8}{*}{ Estagiários } & \multirow{8}{*}{$\begin{array}{c}\text { Nesta etapa, os } \\
\text { estagiários } \\
\text { participaram } \\
\text { indiretamente por } \\
\text { meio das } \\
\text { observações } \\
\text { realizadas pela } \\
\text { pesquisadora }\end{array}$} & \multirow{4}{*}{ E1 } & E3 & \multirow[t]{8}{*}{10} \\
\hline & & & E4 & \\
\hline & & & E5 & \\
\hline & & & E6 & \\
\hline & & \multirow{4}{*}{ E2 } & E7 & \\
\hline & & & E8 & \\
\hline & & & E9 & \\
\hline & & & E10 & \\
\hline Total por etapa & 11 & 9 & 27 & \\
\hline \multicolumn{4}{|c|}{ Total de participantes diretamente envolvidos } & 42 \\
\hline
\end{tabular}

Fonte: elaborado pelos autores.

Com relação aos estagiários que participaram dos grupos focais em ambas as etapas, cabe destacar que se encontravam em semestres posteriores, isso significa que participaram dos grupos focais após finalizarem a disciplina de estágio. Assim sendo, cabe localizar o semestre em que se encontravam no momento de realização do grupo focal, bem como outras informações que foram reunidas e consideradas para estudo no quadro 2:

Quadro 2 - Caracterização dos Estagiários

\begin{tabular}{|c|c|c|c|l|}
\hline Estagiário & $\begin{array}{c}\text { Semestre em } \\
\text { que se } \\
\text { encontrava }\end{array}$ & $\begin{array}{c}\text { Participava de } \\
\text { Grupos de } \\
\text { Estudos ou de } \\
\text { Pesquisa }\end{array}$ & $\begin{array}{c}\text { Outra } \\
\text { formação }\end{array}$ & Atividade que exercia \\
\hline E-1 & $8^{\circ}$ & Não & Não & $\begin{array}{l}\text { - Atividade profissional externa à } \\
\text { educação }\end{array}$ \\
\hline E-2 & $8^{\circ}$ & Sim & Não & - Bolsista PIBID \\
\hline E-3 & $6^{\circ}$ & Não & Magistério & - Professor Ensino Fundamental I \\
\hline E-4 & $8 .^{\circ}$ & Sim & Não & - Bolsista PIBID - EJA \\
\hline E-5 & $6 .^{\circ}$ & Sim & Não & - Bolsista - Iniciação Científica \\
\hline E-6 & $6 .^{\circ}$ & Sim & Não & - Bolsista - Iniciação Científica \\
\hline E-7 & $6 .^{\circ}$ & Sim Recreação (Free Lancer) \\
\hline E-8 & $6 .^{\circ}$ & Sim & Educação & - Professora de Educação Física \\
\hline E-9 & $6 .^{\circ}$ & Sim & Não & - Bolsista - Iniciação Científica \\
\hline E-10 & $6 .^{\circ}$ & Sim & Não & - Bolsista - Iniciação Científica \\
\hline
\end{tabular}

Fonte: elaborado pelos autores.

No que se refere à professora supervisora, informa-se que ela cursou a Habilitação Específica para o Magistério e é graduada em Pedagogia, com mestrado e doutorado em Educação, desenvolvendo pesquisas relativas à formação docente.

A pesquisa empírica foi desenvolvida em três etapas. Na primeira (março a novembro de 2013), realizamos grupos focais nas escolas, sendo: dois encontros de 60 minutos na Escola $A$, da qual participaram duas professoras e uma coordenadora; na Escola $B$ também foram realizados dois encontros, totalizando 120 minutos de gravação, com a participação de duas professoras e duas coordenadoras; e um encontro de 90 minutos na Escola $F$, que contou com a participação de três professoras e um diretor. Ainda na primeira etapa, também foram realizadas observações na disciplina que ocorria na universidade, durante oito encontros de 4 horas cada um (totalizando 36 horas), a fim de coletar informações a respeito da compreensão de cada um sobre o processo de estágio e como este poderia ocorrer.

Na segunda etapa (março a junho de 2014), a partir dos resultados reunidos inicialmente, elaboramos dois dispositivos de formação, sendo um voltado aos estagiários e outro direcionado aos professores-parceiros. Esses dispositivos foram apresentados às escolas e professores em reuniões com 
tal finalidade. Nessa fase, também acompanhamos todo o processo de implementação dos dispositivos no âmbito das disciplinas em questão (perfazendo um total de 40 horas de acompanhamento) e em seguida realizamos novos grupos focais, sendo um na Escola B (com a participação de uma coordenadora e quatro professoras), um na Escola $G$ (do qual fizeram parte duas professoras) e um grupo focal com duas estagiárias, a fim de avaliar o processo de desenvolvimento dos dispositivos.

$\mathrm{Na}$ terceira etapa (abril a setembro de 2015), continuamos com mais 44 horas de acompanhamento das disciplinas na universidade e novos grupos focais com a finalidade de avaliar a implementação dos dispositivos, participando desse momento: Escola A (cinco professoras e a vicediretora); Escola B (cinco professoras e uma coordenadora); Escola F (três professoras); Escola G (duas professoras); Escola L (três professoras e uma coordenadora); dois encontros com oito estagiários.

O conjunto de dados reunido ao longo desse processo foi analisado a partir de elementos oferecidos pela análise de conteúdo. Respeitando-se as particularidades da pesquisa, levamos em consideração as proposições de Bardin (1979) e André (1983). Os resultados foram organizados em três categorias principais, as quais são apresentadas a seguir.

\section{DISPOSITIVOS DE FORMAÇÃO: ENTRE O IDEAL, A IMPLEMENTAÇÃO E O VIVIDO}

Os dispositivos de acompanhamento de estágio elaborados no âmbito desta pesquisa partem de uma perspectiva teórica analítico-reflexiva, englobando aspectos de uma formação pautada na análise de práticas e em uma abordagem reflexiva (SMYTH, 1991; SCHON, 1992). Tais dispositivos são aqui apresentados tomando-se como base três dimensões identificadas por Albero (2010, tradução nossa): ideal, operacional ${ }^{10}$ e vivido. Tais dimensões tomam como base a "observação empírica das dificuldades recorrentes encontradas pelos atores, as tensões, contradições e paradoxos os quais se confrontam" (ALBERO, 2010, p. 56).

$\mathrm{Na}$ dimensão ideal, apresentamos o dispositivo tal como ele foi idealizado; na dimensão operacional, exploramos sua implementação, ou seja, o modo como ele foi manuseado e apropriado pelos participantes a partir dos nossos registros advindos do acompanhamento de todo o processo; na dimensão vivida, elencamos, a partir do relato dos participantes, o que de fato pensaram sobre sua experiência e seu envolvimento com os dispositivos. Optamos por assim apresentar as dimensões consideradas em função do grande volume de dados reunidos nas diferentes etapas e instrumentos que compuseram nosso estudo de campo. As três dimensões elencadas pareceram-nos pertinentes do ponto de vista organizacional e temático, permitindo-nos destacar elementos essenciais que fossem ao encontro dos objetivos da investigação.

\section{O dispositivo em sua Dimensão Ideal}

Para Albero (2010), a primeira dimensão é composta por princípios e por um conjunto de ideias, modelos e valores que estruturam os atos e discursos durante a realização da proposta. "A dimensão ideal do dispositivo é sua bússola e seu fio condutor, seu propósito explicitamente declarado ou não" (ALBERO, 2010, p. 56, tradução nossa). Portanto, tal dimensão orienta a ação daqueles que conceberam e dos que são responsáveis pelo dispositivo sem, no entanto, partilhar desse conjunto de ideias com todos os atores envolvidos. Partindo dessa compreensão, apresentamos os dispositivos da forma como foram idealizados, concebidos e quais valores e modelos de formação estão implícitos. Baseados nos pressupostos do movimento de profissionalização do ensino (BOURDONCLE, 2000), os dispositivos pautam-se nas perspectivas de análise das práticas (ALTET, 2000) e de prática reflexiva (SCHON, 1992; PERRENOUD, 2004).

\footnotetext{
${ }^{10}$ No original, o autor emprega a expressão Fonctionnel de Référence; mas no presente estudo optamos pelo termo Implementação, por compreender que tal dimensão se refere ao funcionamento ou à operacionalização do dispositivo.

Educação em Revista|Belo Horizonte|v.36|e228755|2020
} 
As questões orientadoras para a construção de nossos dispositivos foram: como pensar o estágio de prática de ensino de modo a ultrapassar o aprendizado baseado na tentativa-erro e/ou na ênfase exclusiva na dimensão afetiva? Que elementos profissionais poderiam compor um dispositivo de acompanhamento de estagiários? Como inserir o professor-parceiro na formação do estagiário de modo que ele possa se valer de sua experiência e saberes profissionais para orientar o aprendiz?

Partindo dessas questões e da perspectiva do acompanhamento compartilhado, os dispositivos foram elaborados assumindo duas funções principais: de um lado, auxiliar o estudante na reflexão de sua prática, oferecendo-lhe uma perspectiva profissional para a consideração de sua experiência no estágio e, de outro, oferecer um papel mais ativo na formação ao professor-parceiro, que parta da recepção dos estagiários para seu acolhimento (SARTI; ARAÚJO, 2016), e que avance ainda mais em direção às práticas de acompanhamento, de modo a ocupar mais amplamente seu lugar na formação das novas gerações de professores (SARTI, 2013).

Nessa perspectiva, foram elaborados dois dispositivos formativos de acompanhamento: Roteiro de Acompanhamento Analítico-Reflexivo (RAAR) e Roteiro de Acompanhamento da Prática de Ensino (RAPE). O primeiro é dirigido aos estagiários, sendo utilizado e manejado por eles, composto por quatro itinerários que acompanham diversas etapas do estágio: 1. Expectativas; 2. Notícias e Organização; 3. Acompanhamento da própria prática; 4. Reflexivo e Desprivatização da prática. Já o RAPE é composto por três roteiros utilizados pelos professores para acompanhar os estagiários, quais sejam: 1. Fase Inicial do Estágio: entrada em sala de aula e Planejamento do Trabalho; 2. Sobre o Plano de Trabalho elaborado em parceria com a professora; e 3. Fase de Desenvolvimento do Plano de Trabalho.

Para elaborar ambos os dispositivos, inicialmente, identificamos que o estágio decorre de um ciclo de desenvolvimento (CYRINO; SOUZA NETO; SARTI, 2016) que compreende três fases principais que se sucedem: normatização (de 1 a 4 semanas - diz respeito à entrada no universo do estágio, período em que os estudantes se preocupam com aspectos organizacionais e institucionais do estágio, concebendo-o como mais uma tarefa da universidade); produção e descoberta (de 5 a 10 semanas - os estagiários percebem outras preocupações, descobertas e algumas conquistas, como as atividades adequadas para cada faixa etária, o projeto de estágio, a elaboração de planos de aula, colocarem-se como professores e a criação de vínculos afetivos com os alunos e com o professorparceiro); e percepção da docência e desenlace compulsório (de 11 a 16 semanas - corresponde ao momento em que os estagiários percebem aspectos do trabalho e do cotidiano docente, mas, ao mesmo tempo, precisam se despedir sem almejar a separação pessoal com os alunos e a escola).

Tendo em vista essa temporalidade identificada no estágio, a supervisora e a pesquisadora elaboraram conjuntamente um instrumento para auxiliar os estudantes a acompanharem e refletirem sobre seu percurso no estágio e sobre sua própria prática. O RAAR é composto por itinerários que acompanham diversas etapas do estágio: Expectativas; Notícias e Organização; Acompanhamento da própria prática; Reflexão e Desprivatização da prática (COCHRAN-SMITH, 2012). Por meio desse itinerário, os estagiários realizam o momento de "desprivatização da prática" (COCHRAN-SMITH, 2012) em sala de aula, atividade em que revisitam os registros realizados sobre suas aulas e realizam o exercício de descrevê-las oralmente, socializando com os colegas, que podem, então, auxiliá-los na compreensão de suas ações e possibilidades de mudança.

Tal exercício, pautado na "interrupção do ensino como um ato privado", possibilita que, desprivatizando suas ações e práticas de forma sistematizada, os estagiários mudem o olhar para a experiência vivida e transformem suas atitudes. Nessa perspectiva, "a mudança é provocada por uma variedade de perspectivas e processos que abrem o ensino aos outros" (COCHRAN-SMITH, 2012, p. 112, tradução nossa), compreendendo que "o refletir nesse contexto necessita incorporar os dados dos outros e, desse modo, ampliar possibilidades concretas de trabalho coletivo" (AROEIRA, 2014, p. 127). Assim, oferece à dimensão reflexiva um "caráter público e ético" (PIMENTA, 2002, p. 43).

Paralelamente ao roteiro dos estudantes, elaboramos também o já mencionado RAPE, que é direcionado aos professores, para possibilitar sua colaboração sistematizada em aspectos da formação dos estagiários e oferecer ao estagiário um feedback de seu estágio. A noção de feedback assumida no trabalho refere-se ao carácter dialógico, interativo, relacional dos processos vivenciados pelos 
estudantes, à eleição da aprendizagem como o objetivo final, bem como ao reconhecimento da natureza variada dos contextos envolvidos (ALARCÃO; LEITÃO; ROLDÃO, 2009).

Os dispositivos descritos - o RAAR e o RAPE - apontam para a possibilidade do acompanhamento compartilhado do estágio, que incluía elementos referentes à gestão de classe, às atitudes profissionais (pontualidade e modos de se vestir) ${ }^{11}$, às relações interpessoais (interações com os alunos e com a professora da classe), à comunicação (vocabulário empregado), ao planejamento (materiais previamente organizados), à percepção sobre o ensino, à didática (objetivos da aula, inclusão de todos os alunos nas atividades propostas) e à prática reflexiva (atentar para os elementos focalizados pelos dispositivos e partilhar suas impressões com os colegas).

Partindo da noção de ação pedagógica (PERRENOUD, 2001), compreendemos que aprendizagens profissionais mais amplas, relativas aos elementos anteriormente apresentados nos dispositivos, não ocorrem durante o estágio. São construídas progressivamente no decorrer dos anos de trabalho docente e, pouco a pouco, estabelecem-se em rotinas que são controladas pelo habitus, que, por sua vez, é composto a partir da construção social das disposições necessárias a um determinado campo - disposições estas que são "o princípio gerador e unificador do conjunto das práticas e das ideologias características de um grupo de agentes” (BOURDIEU, 2002 [1966], p. 118). Assim, quando o conjunto de esquemas de ação se integra na formação de um habitus, ele é transformado em uma rotina, que inconscientemente possibilita todas as ações do sujeito (PERRENOUD, 2001).

O estágio é um momento formativo em que, geralmente, os agentes não contam com esquemas de ação docente, na forma de um habitus específico (PERRENOUD, 2001), que lhes permitam ultrapassar os procedimentos mais rotineiros e previsíveis ligados ao ensino. Refere-se a uma fase da formação em que o futuro professor "tenta ainda trabalhar os saberes procedimentais, as receitas, as técnicas, os métodos, os modelos" (PERRENOUD, 2001, p. 185). Assim, quando o estagiário vive a experiência de ensinar, ele está centrado em realizar os processos do ensino, cumprir com as regras que lhe foram postas, seguir à risca o plano da aula que preparou etc. Nesse caso, "o habitus opera na implementação destes procedimentos e esquemas de ação" (PERRENOUD, 2001, p. 185, tradução nossa). Os esquemas de ação são ligados à maior parte de nossas operações mentais e ações, como pensamento, percepção, decisão, julgamento, avaliação etc. (PERRENOUD, 1994). Esses esquemas fazem parte das ações mais inconscientes do sujeito, caracterizando-se como rotinas. E é a partir desse processo que se constitui a ação docente.

No caso da formação para a docência, os estagiários ainda não possuem as rotinas docentes, podendo adquiri-las no momento da socialização profissional de pelo menos duas formas: na primeira, pela tentativa-erro, o estagiário não é desafiado a resolver situações, mas a observar como se faz e posteriormente tentar "fazer do seu jeito" (PERRENOUD, 2001), o que pode ocasionar na reprodução de práticas já existentes sem ter a consciência do que de fato se faz e incorporando-as em seus esquemas profissionais; já na segunda maneira, segue-se a ideia de compreender as situações de ensino, agindo sobre elas e analisando-as para, em seguida, modificar ou não os modos de fazer, o que seguiria uma perspectiva profissional da formação. De uma forma ou de outra, o habitus se constrói (PERRENOUD, 2001), sendo incorporado paulatinamente.

Porém, para não corrermos o risco de os futuros professores reproduzirem práticas vivenciadas quando eram estudantes (TARDIF; RAYMOND, 2000), e de suas aprendizagens no estágio serem relegadas à mera tentativa-erro, é importante que os estagiários tenham contato com situações reais de ensino. Para esse fim, com o auxílio do professor experiente, oferecemos ferramentas para que eles possam sistematizar e refletir sobre suas ações, a fim de constituir, aos poucos, seus esquemas, ressignificando suas crenças e concepções, constituindo um habitus profissional. É nesse sentido que os dispositivos de formação buscam favorecer a reflexão crítica, auxiliando os estagiários na compreensão de suas ações, de modo que fundamentem o que fazem, procurando identificar os pressupostos (ligados a teorias acadêmicas ou não) que ancoram nas práticas de ensino, mas sem perder a capacidade de reconstruir ou de poder transformar as ações e práticas de ensino (SMYTH, 1991).

11 Os itens colocados entre parênteses são exemplos de questões contidas nos dispositivos. Educação em Revista|Belo Horizonte|v.36|e228755|2020 
Para além das possibilidades de reflexão, a implementação de dispositivos como os aqui propostos afina-se com os propósitos de profissionalização do ensino, posto que está "ligada à construção da compreensão da prática" (MARCEL et al., 2002, p. 139, tradução nossa) e, portanto, à concepção do ensino como atividade complexa.

\section{A implementação dos dispositivos}

Apresentamos aqui o dispositivo implementado tal como foi projetado, englobando todo o seu conteúdo, bem como seu funcionamento em relação à atividade de cada ator (ALBERO, 2010). Descrevemos, portanto, o modo como os participantes se apropriaram desses instrumentos formativos durante as etapas dois e três, quando foram implementados e o trabalho foi acompanhado. Partimos dos registros de campo elaborados durante o acompanhamento da disciplina nessas duas etapas e dos resultados de nossas percepções, diálogos informais, inclusive envolvendo estagiários e professoras. Os dados dizem respeito também às visitas realizadas às escolas.

Após o primeiro contato dos estagiários com o documento RAAR e sua implementação no estágio, a supervisora propôs uma discussão a seu respeito durante a aula, para que os estagiários pudessem partilhar suas experiências no emprego desse recurso. Muitos dos estagiários de 2014 pontuaram que o documento solicitava um número excessivo de informações, gerando uma atividade de registro muito intensa. Destacaram, porém, que as questões contidas no roteiro lhes pareceram importantes para o momento de reflexão sobre a prática, oferecendo-lhes parâmetros para a seleção do que poderiam anotar e observar sobre suas ações.

O grupo em estágio no ano de 2015, no entanto, mostrou alguma resistência à implementação do documento. Como o documento lhes foi apresentado somente na sexta aula (em função de especificidades no calendário letivo), muitos estudantes já haviam iniciado as atividades de regência no estágio e organizado de forma independente seus registros do ocorrido nas aulas. Ao apresentarmos o documento, esses estudantes mostraram-se inquietos, não encontrando sentido na retomada dos registros em função das questões propostas pelo RAAR. Ademais, uma estudante questionou o teor das questões, por considerá-las demasiadamente simples e, portanto, limitadoras da reflexão. Argumentou que, sobre sua prática no estágio, realizou um registro mais livre de cada aula, escrevendo apenas os elementos que lhe apresentam algum sentido. Diante da polêmica gerada pela manifestação da estudante, a supervisora e a pesquisadora intervieram explorando junto à turma cada questão do documento, explicitando seus fundamentos teóricos, os motivos pelos quais foram propostos. Ficou mais clara para o grupo a pertinência das questões para o acompanhamento da prática de professores em formação inicial e sua vinculação com a experiência de estágio naquela rede de ensino, posto que tais questões tinham sido formuladas a partir dos grupos focais realizados com as professoras parceiras.

Durante a discussão estabelecida na turma, alguns estudantes ressaltaram, como havia ocorrido na turma anterior, a importância de serem inquiridos sobre aspectos da prática pedagógica sobre os quais não teriam atentado. Exemplo nesse sentido foi a questão "Consegui incluir e atingir todos os alunos no trabalho proposto?". De acordo com esses estudantes, sem tal questão eles não teriam percebido que suas aulas tinham sido elaboradas tendo em vista somente os alunos que não apresentavam maiores dificuldades, alunos ideais. Frente a essa constatação, os estudantes consideraram que nas aulas seguintes, que ainda seriam elaboradas, deveriam levar em consideração atividades para os alunos com dificuldade de aprendizagem, fato que seria um desafio e deveria ser conversado com a professora responsável pela classe. A maioria dos estudantes pareceu concordar com esses apontamentos, oferecendo exemplos relativos a suas experiências no estágio.

Nas aulas seguintes da disciplina, o último dos quatro documentos do RAAR, o Documento de Acompanhamento da Própria Prática, foi trabalhado em uma dinâmica elaborada a partir da noção de "desprivatização da prática" (COCHRAM-SMITH, 2012) e baseada nas etapas reflexivas descritas por Smyth et al., (1999). A supervisora solicitou que os estagiários se organizassem em grupos de, no máximo, quatro integrantes, tendo como critério de agrupamento o ano escolar em que realizavam o 
estágio (ficaram em um mesmo grupo estagiários que realizaram o estágio no $1^{\circ}$ ano; no $2^{\circ}$ ano etc.). Cada estudante deveria então escolher uma das aulas que havia ministrado para relatá-la em detalhes para os colegas. Tiveram como apoio para essa descrição da aula as respostas que tinham elaborado para as questões do Documento de Acompanbamento da Própria Prática. A partir do relato inicial, deveriam passar para a discussão das questões presentes no documento Reflexão 3': Por que fiz assim? É possível fazer diferente? O que eu mudaria nesta aula? A supervisora e a pesquisadora - acompanhadas pela monitora da turma, uma estudante pós-graduanda em estágio docência - distribuíram-se em cada grupo para orientar as discussões, propondo questionamentos que os fizessem refletir sobre a situação apresentada.

A intenção era que os estudantes pudessem aprofundar as reflexões que tinham elaborado inicialmente, buscando outros elementos que ultrapassassem o imediatamente perceptível na aula, avançando para uma aproximação mais analítica com suas práticas. O que observamos é que, em alguns grupos, a finalidade dessa dinâmica foi atingida. Os estudantes apropriaram-se das questões e realizaram a dinâmica como previsto, dispersando-se em alguns momentos para relatar situações vividas nas aulas que consideravam desafiadoras, relativas às atividades que haviam desenvolvido ou, ainda, sobre os alunos.

Cabe destacar que as discussões entre os estudantes fluíam bem sem, no entanto, que eles de fato se orientassem pelo roteiro proposto para discussão. A adesão ao roteiro parecia ser assumida como uma tarefa escolar, que era cumprida somente na presença de uma das três figuras docentes com as quais eles se relacionavam ali (a supervisora, a monitora e também a pesquisadora). Nos outros momentos, os relatos mostravam-se mais livres e, no lugar das análises sistemáticas esperadas, ouvíamos conversas animadas entre os estudantes.

Assim, o que se encontra é a falta, ainda, da incorporação de um "ponto de vista pedagógico" (AZANHA, 2006), ou seja, "uma perspectiva especificamente docente, que possibilite aos estudantes o discernimento nas situações de ensino e a tomada de decisões" (SOUZA NETO, SARTI, BENITES, 2016, p. 316). Porém, essas ações dos estudantes podem ocorrer também em função de uma naturalização da "disprivatização da prática" (COCHRAM-SMITH, 2012), das vivências e experiências de ensino, de forma não sistematizada - o que não deixa de ser importante. Entretanto, para que elas ganhem densidade e reconhecimento pedagógico, na forma de saberes da ação pedagógica (Gauthier et al, 1998), precisam ser fundamentadas e tornadas públicas. Sobre essa questão, Lessard (1999) compreende que os conhecimentos específicos da ação pedagógica possuem sua equivalência no que Shulman (1987) chama de conhecimento pedagógico de conteúdo, Gauthier et al. (1998) denomina de saberes da ação pedagógica e Barbier (1996) concebe como saberes da ação. Concluindo, esse conhecimento específico da ação pedagógica pode ser denominado também de conhecimento profissional docente (NÓVOA, 2019).

\section{O Dispositivo vivido: uma breve apreciação da experiência dos participantes, avanços e limites}

A partir de dados reunidos por meio dos grupos focais, dos registros livres realizados sobre as visitas às escolas e das observações nas aulas da disciplina realizada na universidade, buscamos identificar elementos da dimensão vivida pelos participantes da pesquisa. Por dimensão vivida, entendemos a "interpretação subjetiva ligada às suas disposições e biografia, aspirações e sistemas de interesse, mas também às suas intenções e objetivos explícitos ou não [...]” (ALBERO, 2010, p. 57, tradução nossa). Dados sobre essa dimensão possibilitam-nos uma retomada dos dispositivos de formação elaborados, de modo a avaliá-los e, se for o caso, reelaborá-los. Entendemos que as vivências que os atores tiveram dos dispositivos propostos os "levam por vezes a realizações muito diferentes daquela que estava planejada" (ALBERO, 2010, p. 57, tradução nossa).

Informações reunidas no âmbito dos grupos focais (realizados em 2014 e em 2015) e das discussões entre pesquisadora e supervisora possibilitaram certas percepções sobre a dimensão vivida relativa ao emprego dos dispositivos, o que nos permite, neste momento, retornar às intenções do dispositivo e observar como foram percebidas e vividas pelos participantes. Vinculamos, portanto, tal 
análise a três aspectos: relatos dos participantes relativos à funcionalidade do dispositivo; como ocorreu o processo de reflexão sobre a prática; e de que maneira o papel do professor parceiro foi percebido.

\section{Dispositivos e sua funcionalidade}

No que se refere ao primeiro aspecto, nossos registros permitiram-nos identificar que o RAPE se mostrou como dispositivo acessível aos professores, principalmente no que diz respeito ao tempo despendido para sua elaboração, assumindo um papel importante para os integrar mais amplamente no estágio. Quanto ao estagiário, o dispositivo mostrou seu potencial formativo. Para a universidade, revelou-se como bom instrumento de feedback e de aproximação com a escola. O conteúdo das questões presentes no documento mostrou-se adequado e não nos pareceu necessário qualquer alteração nesse sentido.

O Roteiro dos estudantes (RAAR) também foi considerado relevante para o acompanhamento do estágio, especialmente no que se refere à possibilidade de um auto engendramento no estágio, favorecendo-lhes percepções sobre seu próprio processo de desenvolvimento no período. Os estagiários ressaltaram a importância desse roteiro para sua organização pessoal durante o estágio, para a elaboração dos materiais exigidos pela disciplina, bem como para orientar suas interações com a professora da escola (seria interessante, por exemplo, indagar sobre a rotina escolar). Cabe destacar, ainda, que o roteiro assumiu relevância também para o trabalho de acompanhamento do estágio por parte da supervisora.

Neste sentido, de um lado, Tardif (2002) lembra-nos que os saberes profissionais dos professores, sendo saberes de seres humanos para seres humanos, envolvem uma dimensão emocional; esses saberes podem suscitar uma teoria da interação social, pois a prática educativa como interação desencadeia processos de negociação mútua sobre os próprios papéis sociais. Assim, a interação no trabalho de acompanhamento do estágio envolve interações linguísticas, expressa sentimentos em relação ao outro e conecta-se à uma orientação dos comportamentos de um ser humano (TARDIF, 2002). Por outro lado, o uso do roteiro, na forma de um dispositivo, possibilita a análise, reflexão e fundamentação da prática (ALTET, 2000), bem como nos possibilita passar de um ofício artesanal para a perspectiva da docência como profissão, na incorporação de uma cultura profissional.

\section{Reflexão sobre a prática}

Nesse itinerário, os professores-parceiros que participaram do grupo focal observaram a importância de o estagiário ter aspectos definidos para observar e os avanços que tal definição possibilita para a atividade de preparação de aulas por parte dos estagiários. Um dos aspectos que nesse sentido foram destacados acerca dos dispositivos foi a reflexão:

"PB-3: é uma reflexão em cima do que eles trabalharam...

PB-4: é!

PB-5: e até para o relatório deles!

$[\ldots]$

PB-2: e se o ponto é reflexão eu acho que conseguiu contemplar nas fichas que vocês propuseram para nós, nessa ficha que você mostrou, para eles...eu acho que o papel do professor é a reflexão o tempo todo. Não só na reflexão, mas partir daí para reestruturar..." (Grupo Focal 2, Escola B - 01/07/2014).

Os estagiários também relataram a importância desse aspecto:

"E-2: eu não ia pensar para refletir em tanta coisa assim... tinha pergunta lá que...que eu falava: 'ai, eu não pensei nisso, então vou ter que pensar!”' (Grupo Focal 2, Estagiários 18/08/2014).

E reconheceram que é possível confrontar o seu dispositivo com aquele voltado à professora: 
“E-6: [...] Aquele lá é mais da professora responder, mas...

E-9: mas dá para juntar os dois, porque eu estava olhando aqui, esse último que ela vai analisar a nossa prática, se pegar... a minha [professora] fez algumas anotações, mas aí se pegar, dá para... E-6: dá para você comparar...

E-9: é... sabe, e elaborar bem o relatório. (...) é, eu consegui, porque eu ia olhando nas anotações e ia fazendo...

E-6: é, eu fiz a mesma coisa...” (Grupo Focal 3y, Estagiários - 25/09/2015).

No Grupo Focal da Escola G, as professoras também sinalizaram que, ao preparar uma aula, o professor deve pensar em alguns dos elementos, como o objetivo da aula, os conteúdos, o tempo previsto, a inclusão de todos os alunos, dentre outros. Alguns desses elementos estão contidos no dispositivo, o que pode adiantar essa etapa para o estagiário. Sobre esse assunto, os estagiários disseram que o dispositivo foi muito importante, pois os estimulou a considerar aspectos relevantes para a docência que, de outro modo, poderiam não ter sido percebidos por eles.

Assim, os dispositivos colocaram em destaque elementos vinculados à prática docente cotidiana, possibilitando ao estudante realizar uma reflexão "sobre a experiência que se está vivenciando" e posteriormente registrar, repensando sua experiência, ressignificando seu olhar sobre a escola e a prática (ZABALZA, 2014, p. 169).

Para além dos dispositivos, esse exercício reflexivo deve ser estimulado também pela intervenção formativa do supervisor de estágio, ao auxiliar o estagiário a "pensar de uma forma mais elaborada o que o fez agir dessa ou daquela forma, ou quais conhecimentos, princípios, valores foram mobilizados para orientar sua prática pedagógica na escola" (SILVESTRE; PLACCO, 2011, p. 42). Tal perspectiva confere, portanto, ao estágio "um estatuto epistemológico que supera sua tradicional redução à atividade prática instrumental” (ALMEIDA; PIMENTA, 2014, p. 9).

A partir dos dados anteriormente apresentados, bem como nos recorrentes diálogos com a supervisora durante o processo dos estágios e o acompanhamento da disciplina, foi possível identificar pontos positivos no desenvolvimento dos dispositivos, que possibilitaram aos estagiários: a sistematização das aulas e da própria experiência; a organização de materiais; a reflexão sobre a prática e a observação do contexto escolar como um todo, englobando o ambiente e o trabalho do professor; e, por fim, a organização dos alunos.

\section{Os dispositivos formativos e o papel do professor-parceiro no estágio.}

No âmbito da pesquisa realizada, foi possível perceber que os professores reconheceram sua inserção na discussão sobre o estágio e a delimitação mais clara do papel que deveriam nele desempenhar. Parece que vivenciaram uma oportunidade de compreender em que medida sua experiência profissional pode colaborar com a formação de uma nova geração docente (SARTI, 2009, 2013). Com os dispositivos em mãos, os professores-parceiros sentiram-se, de modo mais formalizado, parte do processo de orientação do estagiário.

Como previsto pela proposta de estágio que a supervisora desenvolve, as professoras dispuseram-se a auxiliar os estagiários, realizando o planejamento de aulas em conjunto. As docentes reconheceram que, para além do planejamento, poderiam auxiliar os estagiários na definição de questões mais específicas, como, por exemplo, os objetivos pedagógicos das aulas.

"PL-2: Então assim, ela planejava essa aula e quando eu tinha o HTPI,[...] a gente sentava, via a aula, então ela me deixava intervir nesse momento, sugerir [...]: “olha, isso aqui acho que não vai funcionar, ou isso não vai funcionar bem do jeito que você está pensando”. Ela era muito sensível para aceitar essas sugestões.

$[\ldots]$

PL-1: [...] eu lembro uma ocasião que a gente conversou sobre isso e ela veio com esse comentário: “ah, foi legal, acho que eles gostaram, participaram”. E a gente que está ali, meio que, eu intervia, mas a deixava muito à vontade, a gente já tinha planejado junto [...]. E aí eu comecei a questionar: "você percebeu fulano?" [...]. Interessante, o que para gente é tão comum, aquilo que a gente conversa, é tão natural você enxergar todos os alunos e tal, para 
eles não é. Quer dizer, eu comecei a chamar a atenção dela [...] na outra semana ela já começou a ter um... parecia, ter um outro olhar" (Grupo Focal 3, Escola L - 24/09/2015).

"PG-3: uma coisa que às vezes pra gente parece ser uma coisa tão óbvia, para quem nunca fez. Quando eu comecei também, muita coisa eu não sabia como era. Hoje para mim é tranquilo, outros desafios aparecem, mas algumas coisas que para o estagiário é novidade, pra gente não é mais" (Grupo Focal 3, Escola G - 29/09/2015).

Nos últimos dois depoimentos, as professoras parecem perceber que o estagiário ainda não reconhece alguns movimentos e rotinas da aula, como por exemplo a dispersão dos alunos. Essa percepção possibilitou, para a professora em questão, intervir junto à estagiária, chamando sua atenção para aspectos da docência que, para um professor mais experiente, já são óbvios, compreendidos tacitamente, embora ainda inacessíveis para o olhar leigo do estagiário. $\mathrm{O}$ futuro docente ainda não incorporou esquemas da ação pedagógica, pautando-se, portanto, apenas em saberes proposicionais. Entrando em contato com as situações de ensino e recebendo intervenções durante e após sua ação, "pouco a pouco, a parte das rotinas sob o controle da parte menos consciente do habitus aumentará" (PERRENOUD, 2001, p. 185).

Outro ponto ressaltado no depoimento das professoras refere-se ao reconhecimento quanto ao seu papel na orientação do estagiário, quanto aos aspectos próprios da rotina docente e da organização escolar (por exemplo, relativos ao currículo). Para além dos estilos assumidos pela professora na relação com os estagiários, observamos que, mesmo sem contarem com uma função institucionalmente formalizada, eles de fato realizaram atividades relativas à orientação das práticas pedagógicas durante o estágio. Os dispositivos chamaram a atenção para pontos que, no depoimento das professoras, foram importantes de serem destacados na orientação dos estágios. Vale destacar que tal orientação ultrapassou os elementos dos dispositivos propostos, e que as professoras ofereceram informações sobre suas práticas que não estavam previstas nos mesmos. Tais informações atenderam a particularidades de cada relação estabelecida entre professoras e estagiários, potencializando o teor formativo do estágio.

Esse processo, por meio do qual as professoras assumem, mesmo que não sistematicamente e formalmente, a orientação dos estagiários, reconhecendo-se como partícipes da formação dos mesmos, é denominado por Sarti e Araújo (2016, p. 182) como acolbimento formativo, "no qual o professor está mais atento ao processo de aprendizagem profissional docente do estagiário". Para as pesquisadoras, essa modalidade de acolhimento no estágio aproxima-se, mais do que a mera recepção tradicionalmente vivida nessas situações, da ideia do acompanhamento (que orienta os dispositivos de formação aqui discutidos), na qual "o formador se responsabiliza pela elaboração e implementação de dispositivos específicos que possibilitem a atividade de acompanhamento do sujeito em formação" (SARTI; ARAÚJO, 2016, p. 183). Elas pontuam que, para passar de um processo de acolhimento formativo a um processo de acompanhamento propriamente dito, se faz necessário que o professor da escola desenvolva "práticas bastante intencionais e sistemáticas como formador de campo” (SARTI; ARAÚJO, 2016, p. 182).

Nessa mesma direção, compreendemos que a inserção do estagiário na escola, além de possibilitar sua formação, sua vivência no ambiente escolar e no cotidiano do trabalho docente, traz, aos professores que o acolhem, possibilidades formativas, ligadas à reflexão profissional. $O$ estágio pode ser, assim, uma experiência de formação em 'mão dupla' - para os estagiários, mas também para os professores já experientes na docência, "um espaço propício para inovações, viabilizadas especialmente pela união entre a disposição (de tempo e de energia) das estagiárias e a perspicácia pedagógica das professoras envolvidas" (SARTI, 2013, p.88).

É possível inferir que as professoras, ao relatarem tais aspectos sobre a cultura do magistério, clamam pela necessidade de espaços reais de partilha, de compartilhamento de práticas (NÓVOA, 2011), momentos em que possam realizar trocas, dúvidas e sugestões acerca de suas práticas, de forma pontual (atividades, materiais pedagógicos), bem como de forma ampla (se pensarmos na possibilidade de aprofundar tal compartilhamento para a análise das práticas e de casos reais de ensino, por exemplo). 
No que se refere mais especificamente às potencialidades dos dispositivos propostos e aqui explorados, os dados apresentados sugerem que os mesmos: 1. foram considerados práticos e objetivos pelos participantes da pesquisa, facilitando sua utilização; 2. foram assumidos pelos estagiários como recursos para sua organização no estágio; 3. estimularam a reflexão dos participantes; 4. favoreceram a partilha de experiências entre os estagiários nas aulas da disciplina, na universidade; contribuíram para a delimitação de um lugar, para a escola e seus professores, na formação dos futuros professores; 5. potencializaram a dimensão formativa do estágio, favorecendo o engendramento de disposições docentes por parte dos estagiários.

Sob o ponto de vista das três dimensões aqui consideradas (ideal, operacional e vivida), é possível identificar tensões no que se refere ao modo como os dispositivos foram apropriados e reconhecidos pelos participantes. Elencamos brevemente tais tensões e desencontros. Foi possível observar dois principais limites no que tange à estrutura proposta: 1) poucos avanços na questão da reflexão sobre a prática; 2) o RAPE atingiu somente parte de suas intenções. No que diz respeito ao primeiro aspecto, os dispositivos foram concebidos com o intuito de que os estudantes pudessem refletir e até mesmo analisar suas práticas. No entanto, percebemos que eles tiveram dificuldades para realizar reflexões mais sistemáticas e centradas na prática de ensino. Tais dificuldades foram observadas tanto nos momentos em que eles estavam em situação de "desprivatização da prática" (COCHRAMSMITH, 2012) durante as aulas na universidade, quanto nos relatórios de estágio que produziram. Compreendemos, portanto, que o alcance da prática reflexiva, especialmente para professores em formação inicial na docência, não constitui tarefa fácil, como já nos alertava Alarcão (1996).

No tocante à "desprivatização", parte dos estudantes costumava relatar os eventos vividos na escola, sem necessariamente seguir as orientações prévias do dispositivo e que eram reforçadas pela supervisora. Pareciam priorizar o relato dos acontecimentos que lhes chamavam a atenção na escola, as curiosidades, as (re)descobertas, as relações afetivas que estabeleciam com os alunos etc. Pouco se atinham para os detalhes das aulas que tinham escolhido analisar. O momento de desprivatização era realizado e parecia agradar-lhes, mas era fortemente caracterizado pelo relato de experiências, e não pela perspectiva analítica pretendida.

Sobre o RAPE, observou-se que esse roteiro, em parte dos casos, não foi operacionalizado e vivenciado a partir de sua intenção primeira. Os estagiários relatavam-nos informalmente, e até mesmo nos grupos focais, que os professores preenchiam os documentos quase que para cumprir uma formalidade, sendo que somente alguns o reconheciam como instrumento formativo. Assim, ao receberem o documento preenchido pelo professor-parceiro, não era sempre que os estagiários encontravam o feedback esperado.

Nesse sentido, foram aventadas algumas alternativas para o enfretamento desses limites percebidos. Para que o RAPE seja de fato utilizado pelos professores para realizar um acompanhamento formativo (SARTI; ARAÚJO, 2016) e compartilhado, auxiliando os estagiários a perceberem aspectos importantes relativos às suas ações no ensino, faz-se necessário um melhor preparo dos professores-parceiros. Há diferenças a serem exploradas no que se refere à parceria e ao acompanhamento.

Assim, para além do papel institucional e da organização de sua carga horária, para que o professor-parceiro possa de fato realizar um acompanhamento dos estagiários, fazem-se necessárias ações formativas por parte da universidade que lhes possibilitem assumir um olhar mais atento e analítico quanto à prática docente. Essa formação pode, inclusive, oferecer maior segurança para que o professor-parceiro ouse opinar sobre as ações dos estagiários. Faz-se necessário, também, repensarmos os elementos indicados no roteiro de análise dirigido aos professores-parceiros, bem como rever o modo de apresentar o RAAR aos estudantes, na tentativa de evitar que os dispositivos se tornem prescritivos e meramente burocráticos, sem valor formativo. Outro ponto importante é reorganizar a dinâmica voltada à "desprivatização das práticas" (COCHRAM-SMITH, 2012) e à condução da reflexão, possibilitando uma análise aprofundada de suas ações, aproximando-se de uma reflexão sob a perspectiva crítica (SMYTH, 1991).

De modo mais amplo, a estrutura curricular dos cursos de Pedagogia - mas também das demais licenciaturas - deveria ser reorganizada, de modo que as disciplinas fossem voltadas para apoiar 
essa aproximação reflexiva com o trabalho docente, especialmente no que se refere às ações ligadas ao ensino (considerado aqui não como tarefa única da docência, mas como seu eixo principal).

Tais tensões e possibilidades nos permitem considerar os dispositivos de formação propostos no âmbito da investigação aqui focalizada como instrumentos em movimento. Assim sendo, cabe-nos avaliá-los sob a perspectiva de seu ideal, em convergência ao contexto em que estão inseridos, bem como do ponto de vista daqueles que os vivenciam.

\section{PENSAR O ESTÁGIO SUPERVISIONADO NA PERSPECTIVA DA PROFISSIONALIZAÇÃO DO ENSINO E DA FORMAÇÃO DOCENTE}

A título de conclusão, podemos indicar alguns elementos para a discussão na área, que se relacionam à perspectiva da profissionalização dos professores e de sua formação. $O$ primeiro elemento a ser destacado diz respeito à possibilidade de que a implementação de dispositivos de formação tenha oferecido aos professores-parceiros nos estágios maiores possibilidades de perceber o estatuto do estagiário como agente em processo de iniciação pré-profissional. Trata-se de mobilizar os professores para a orientação dos estagiários, percebidos como futuros colegas. O segundo elemento relaciona-se à construção colaborativa dos dispositivos.

Consideramos que, por maiores que sejam os desafios e entraves, o exercício de ouvir o que a escola tem a dizer e valorizar as concepções e práticas do ambiente escolar para a produção do estágio se constitui em um fator determinante para pensarmos na aprendizagem da docência. Por fim, o último elemento a ser ressaltado relaciona-se diretamente aos dispositivos, os quais devem se conectar à dimensão temporal do estágio, ao seu ritmo. Os estagiários aprendem ao longo do estágio, desenvolvem-se e devem assim ser acompanhados nesse processo. Para tanto, consideramos que a área de formação docente deva atentar para os aportes teóricos da Andragogia, ainda pouco explorada no País. A formação docente deve incluir avanços que vêm sendo alcançados na área da formação profissional e de adultos.

Os dispositivos formulados e implementados na pesquisa aqui relatada pretenderam estimular a perspectiva profissional por parte dos estagiários, favorecendo-lhes aproximações mais analíticas com as práticas docentes. $O$ que se intenta é possibilitar aos futuros professores uma formação de alto nível acadêmico e profissional, que somente será possível com uma efetiva aproximação entre as IES e a escola.

Concluindo, os dispositivos propostos intencionaram potencializar a reflexão sobre as experiências significativas vividas pelos estagiários, na parceria com os professores experientes no ensino, por meio de uma aproximação mais profissional com o trabalho docente. Nesse contexto, outro elemento que se delineia diz respeito à projeção do estágio supervisionado para além de mero espaço de formação, mas também como uma pedagogia que se constrói na prática dessa formação.

Considera-se que a implementação de dispositivos de formação no estágio, como os aqui descritos, favoreça a produção de disposições ligadas ao ensino por parte dos licenciandos, que lhes permitam sentir, pensar e atuar como professores. Tais dispositivos buscam favorecer, também, a tomada de consciência dos agentes sobre a especificidade da ação docente (PERRENOUD, 2001) e sua complexidade, possibilitando ao estudante da licenciatura ressignificar as suas crenças e os seus modelos de prática pedagógica, construídos nos bancos escolares ao longo de sua trajetória como alunos. Trata-se de assumir a formação docente como espaço estratégico, de intervenção, e de nos assumirmos, efetivamente, como formadores de professores.

\section{REFERÊNCIAS}

ALARCÃO, I. Ser professor reflexivo. In: ALARCÃO, I. (org.) Formação reflexiva de professores. Estratégias de supervisão. Porto, Portugal: Porto Editora, 1996. pp. 171-189. 
ALARCÃO, I; LEITÃO, A; ROLDÃO, M. C. Prática pedagógica supervisionada e feedback formativo co-construtivo. Revista Brasileira de Formação de Professores - RBFP. vol. 1, n. 3, p. 02-29, Dezembro/2009.

ALBERO, B. La formation en tant que dispositif : du terme au concept. In : CHARLIER, B.; HENRI, F. Apprendre avec les technologies. Paris : Presses Universitaires de France, 2010, pp. 47-59.

ALMEIDA, M. I.; PIMENTA, S. G. Centralidade do estágio em cursos de didática nas Licenciaturas: rupturas e ressignificações. In.: ALMEIDA, M. I.; PIMENTA, S. G. (orgs.). Estágios supervisionados na formação docente: educação básica e educação de jovens e adultos. São Paulo: Cortez, 2014. pp. 113-151.

ALTET, M. L'Analyse de Pratiques: une démarche de formation professionnalisant ? Recherche et Formation, no 35, 2000, pp. 25-41. Disponível em : http://ife.ens-lyon.fr/publications/editionelectronique/recherche-et-formation/RR035-03.pdf. Acesso: 10 jan. 2014.

ANDRÉ, M. E. D. A. Texto, Contexto e Significados: algumas questões na análise de dados qualitativos. Cadernos de Pesquisa, São Paulo, maio, 1983.

AROEIRA, K. P. Estágio supervisionado e possibilidades para uma formação com vínculos colaborativos entre a universidade e a escola. In: PIMENTA, S. G.; ALMEIDA, M. I. (orgs.). Estágios supervisionados na formação docente: educação básica e educação de jovens e adultos. São Paulo: Cortez, 2014. pp. 113-151.

AZANHA, J. M. A formação do professor e outros escritos. São Paulo: SENAC, 2006.

BARBIER J.-M. Introduction. In: BARBIER, J.-M. (éd.), Savoirs théoriques, savoirs d'action. Paris: PUF, 1996.

BARDIN, L. Análise de conteúdo. Lisboa: Edições 70, 1979.

BOURDIEU, P. Campo de Poder, Campo Intelectual: itinerário de um concepto. Buenos Aires: Editorial Montressor, 2002 [1966].

BOURDONCLE, R. Autour des mots « Professionalisation, Formes et Dispositifs ». Recherche et Formation, n. 35, 2000, pp. 117-132.

BRASIL. Conselho Nacional de Educação. Lei no 9394, de 20 de dezembro de 1996. Lei de Diretrizes e Bases da Educação Nacional. Diário Oficial [da] República Federativa do Brasil, Poder Executivo, Brasília, DF, 20 dez. 1996. Disponível em: http://www.planalto.gov.br/ccivil_03/leis/19394.htm. Acesso em: 3 jun. 2009.

BRASIL. Conselho Nacional de Educação. Parecer CNE/CP n. ${ }^{\circ}$ 28/2001, 2 out. 2001. Diário Oficial [da] República Federativa do Brasil, Poder Executivo, Brasília, DF, Brasília, DF, 02 de out, 2001. Disponível em: http://portal.mec.gov.br/cne/arquivos/pdf/028.pdf. Acesso em: 7 out. 2009.

CHARTIER, Anne Marie. A ação docente: entre saberes práticos e saberes teóricos. In. CHARTIER, Anne Marie. Práticas de leitura e escrita: história e atualidade. Belo Horizonte: Ceale/Autêntica, 2007. p. 185-207. 
COCHRAN-SMITH, M. A Tale of Two Teachers: Learning to Teach Over Time. Kappa Delta Pi Record, vol. 48, n. 3, p. 108-122, 2012. Disponível em: http://dx.doi.org/10.1080/00228958.2012.707501. Acesso em: 10 abr. 2014.

COLE, A.; KNOWLES, J. G. Teacher development partnership research: a focus on methods and issues. American Educational Research Journal, vol.30, n.3, pp.473-495, 1993.

CYRINO, M; SOUZA NETO, S.; SARTI, F. M. Ciclo de desenvolvimento do estágio na aprendizagem da docência. In: III Congresso Nacional de Formação de Professores e do XIII Congresso Estadual Paulista sobre Formação de Educadores: por uma revolução no campo da formação de professores [recurso eletrônico], 11 a 13 de abril de 2016. Anais... Coordenação Maria Lourdes Spazziani, Laurence Duarte Colvara: UNESP/Prograd, 2016, pp. 2068-2076. Disponível em: http://www.unesp.br/anaiscongressoeducadores. Acesso em: 10 dez. 2014.

FABLET, D. Les groupes d'analyse des pratiques professionnelles: Une visée avant tout formative. Connexions, vol. 2, n. 82, 2004, pp. 105-117. Disponível em: http://www.cairn.info/revueconnexions-2004-2-page-105.htm. Acesso em: 13 jul. 2015.

FAINGOLD, N. Formation de formateurs à l'analyse des pratiques. Recherche et Formation, n. 51, pp. 89-104, 2006. Disponível em: < http://ife.ens-lyon.fr/publications/edition-electronique/rechercheet-formation/RR051-07.pdf>. Acesso em: 20 set. 2014.

GATTI, B. A.; BARRETTO, E. S. de S.; ANDRÉ, M. E. D. A.; ALMEIDA P. C. A. Professores do Brasil: novos cenários de formação. Brasília: UNESCO, 2019.

GOMEZ, A. P. O Pensamento Prático do Professor: a formação do professor como profissional reflexivo. In: NÓVOA, A (Org.). Os Professores e a Sua Formação. Lisboa-Portugal: Edições Don Quixote, 1992, pp. 93-114.

GREENBAUM, T. L. The handbook for focus group research. $2^{a}$ ed. California: SAGE publications, 1998.

INEP. Censo 2018: Percentual de Funções Docentes com Curso Superior, Brasil, Regiões Geográficas e Unidades da Federação - 2018. Brasília, 2018. Disponível em:

http://portal.inep.gov.br/web/guest/indicadores-educacionais. Acesso em: 17 jul. 2019.

KRUEGER, R. A.; CASEY, M. A. Focus Groups: a practical guide for applied research.4 ed. California: SAGE publications, 2009.

LESSARD, C. Note critique. Gauthier (C.) et al. (1997). - Pour une théorie de la pédagogie. Recherches contemporaines sur le savoir des enseignants. Revue française de pédagogie, vol. 127, 1999. pp. 172176. Disponível em: < https://www.persee.fr/doc/rfp_0556-

7807_1999_num_127_1_3052_t1_0172_0000_1> Acesso em: 12 ago 2016.

LEVAIN, J-P.; MINARY, J-P. L'analyse de pratiques professionnelles en IUFM. Recherche et Formation, n. 65, 2010. Disponível em:

<https://journals.openedition.org/rechercheformation/167>. Acesso em: 13 fev. 2015.

LÜDKE, M.; ANDRÉ, M.E.D.A. Pesquisa em Educação: Abordagens Qualitativas. São Paulo: EPU, 1986. 
MARCEL, J-F.; OLRY, P.; ROTHIER-BAUTZER, E.; SONNTAG, M. Note de synthèse - Les pratiques comme objet d'analyse. Revue française de pédagogie, vol. 138, 2002. pp. 135-170. Disponível em : http://www.persee.fr/doc/rfp_0556-7807_2002_num_138_1_2872. Acesso em: 12 out. 2015.

MARCELO, C. Formação de Professores: para uma mudança educativa. Porto, Portugal: Porto Editora, 1999.

MICHAUD, C. Interaction des savoirs et des pouvoirs en formation des enseignants : une analyse de discours partenariaux. Nouveaux c@hiers de la recherche en éducation, vol. 6, n 3, 1999, pp. 421440. Disponível em: http://id.erudit.org/iderudit/1016978ar. Acesso em: 20 out. 2014.

NÓVOA, A. Os professores e sua formação. Lisboa: Dom Quixote, 1992.

NÓVOA, A. O regresso dos professores. Pinhais: Melo, 2011.

NÓVOA, A. Entre a formação e a profissão: ensaio sobre o modo como nos tornamos professores.

Currículo sem Fronteiras, vol. 19, n. 1, pp. 198-208, jan./abr. 2019. Disponível em:

https://www.curriculosemfronteiras.org/vol19iss1articles/novoa.pdf. Acesso em: 20 maio 2020.

OLIVEIRA, S. M. O trabalho representado do professor de pós-graduação de uma universidade pública. Doutorado em Linguística Aplicada e Estudos da Linguagem. 260 f. 2011. Pontifícia Universidade Católica de São Paulo, São Paulo, 2011.

PAQUAY, L. et al., Former des enseignants professionnels. Quelles strategies? Quelles competences? Bruxelas: De Boeck Supérieur, 2001.

PEETERS, H.; CHARLIER, P. Contributions a une theorie du dispositif. Hermès, n. 25, pp. 15-23, 1999.

PERRENOUD, P. La formation au métier d'enseignant : complexité, professionnalisation et démarche clinique. In : PERRENOUD, P. La formation des enseignants entre théorie et pratique, Paris : L'Harmattan, 1994, pp. 197-220.

PERRENOUD, P. Le travail sur l'habitus dans la formation des enseignants analyse des pratiques et prise de conscience. In : PAQUAY, L. et al., Former des enseignants professionnels. Bruxelas, Bélgica : De Boeck Supérieur « Perspectives en éducation et formation », 2001, pp. 181-207. Disponível em: < https:/ / www.cairn.info/former-des-enseignants-professionnels--9782804162740-page211.htm\#>. Acesso em: 12 set. 2014.

PERRENOUD, P. L'analyse collective de pratiques comme initiation à la pratique réflexive. In : PERRENOUD, P. Développer la pratique réflexive dans le métier d'enseignant. Professionnalisation et raison pédagogique. Paris: ESF, 2001a, pp.111-130.

PERRENOUD, P. Adosser la pratique réflexive aux sciences sociales, condition de la professionnalisation. Éducation permanente, vol. 160, pp. 35-60, 2004.

PIMENTA, S. G. Formação de Professores: Saberes da docência e Identidade do professor. Nuances. Vol. III, set de 1997. pp. 5-14. 
PIMENTA, S. G. Professor reflexivo: construindo uma crítica. In: PIMENTA, S. G.; GHEDIN, E. (orgs.) Professor Reflexivo no Brasil: gênese e crítica de um conceito. São Paulo: Cortez, 2002. pp. 17-52.

PIMENTA, S. G.; LIMA, M. S. L. Estágio e Docência. 6ª Ed. São Paulo: Cortez, 2011.

REALI, A. M. de M. R.; TANCREDI, R. M. S. P.; MIZUKAMI, M. da G. N. Programa de mentoria online: espaço para o desenvolvimento profissional de professoras iniciantes e experientes. Educ. Pesqui., São Paulo, v. 34, n. 1, p. 77-95, Abr. 2008. Disponível em $<$ http://www.scielo.br/scielo.php?script=sci_arttext\&pid=S151797022008000100006\&lng=en\&nrm=iso> . Acesso: 04 jan. 2012.

SARTI, F. M. Parceria intergeracional e formação docente. Educ. rev., Belo Horizonte, vol. 25, n. 2, ago. 2009. Disponível: <http://www.scielo.br/scielo.php?script=sci_arttext\&pid=S010246982009000200006\&lng=en\&nrm=iso> Acesso: 21 jan. 2010.

SARTI, F. M. Relações intergeracionais e alternância na formação docente: considerações a partir de uma proposta de estágio supervisionado. Cadernos de Educação, n. 46, p. 83-99, 2013. Disponível em: http://periodicos.ufpel.edu.br/ojs2/index.php/caduc/article/view/4174. Acesso em: 12 jan. 2014.

SARTI, F. M.; ARAÚJO, S. R. P. M. Acolhimento no estágio supervisionado: entre modelos e possibilidades para a formação docente. Educação. Porto Alegre, n. 39, v.2, mai-ago, pp. 175-184, 2016. Disponível em: http://revistaseletronicas.pucrs.br/ojs/index.php/faced/article/view/19415. Acesso em: 12 nov. 2016.

SCHON, D. Formar professores como profissionais reflexivos. In. NÓVOA, A. (org.). Os professores e sua formação. Lisboa: Dom Quixote, 1992. pp. 78-93.

SILVESTRE, M. A.; PLACCO, V. N. S. Modelos de Formação e Estágios Curriculares. Formação Docente, Belo Horizonte, vol. 03, n. 05, p. 30-45, ago./dez. 2011. Disponível em: < https://revformacaodocente.com.br/index.php/rbpfp/article/view/44> Acesso em: 13 nov. 2014.

SMYTH, J.; MCINERNEY, P.; HATTAM, R.; LAWSON, M. Teachers Learning Project: Critical Reflection on Teaching and Learning. Flinders Institute for the Study of Teaching, School of Education, Adelaide, South Australia, 1999.

SMYTH, J. Teachers as Collaborative Learners: Challenging Dominant Forms of Supervision. London: Open University Press, 1991.

SOUZA NETO, S.; SARTI, F. M., BENITES, L.C. Entre o ofício de aluno e o babitus de professor: os desafios do estágio supervisionado no processo de iniciação à docência. Movimento, Porto Alegre, vol. 22, n. 1, pp. 311-324, jan./mar. de 2016.

TARDIF, M. Saberes profissionais dos professores e conhecimentos universitários. Elementos para uma epistemologia da prática profissional dos professores e suas consequências em relação à formação para o magistério. Revista Brasileira de Educação. vol. 1, n. 13, pp. 5-24, 2000. Disponível em: http://educa.fcc.org.br/pdf/rbedu/n13/n13a02.pdf. Acesso em: 19 set. 2012.

TARDIF, M. Saberes Docentes e Formação Profissional. Petrópolis, RJ: Editora Vozes, 2002. 
TARDIF, M. ; BORGES, C. ; MALO, A. Introduction. In : TARDIF, M. ; BORGES, C. ; MALO, A.Le virage réflexif en éducation. Où en sommes-nous 30 ans après Schön ? Bruxelas, Bélgica : De Boeck Supérieur, 2012. pp. 7-17.

TARDIF, M.; RAYMOND, D. Saberes, tempo e aprendizagem do trabalho no magistério. Educação e Sociedade, Campinas, vol. 21, n. 73, 2000. Disponível em: http://www.scielo.br/scielo. Acesso em: 29 jul. 2010.

VASQUES, A. L. P. Modelos de formação docente no âmbito da Política Nacional de Formação de Profissionais do Magistério da Educação Básica: pressupostos, ações e dispositivos formativos. 2019, 502f. Tese (Doutorado em Educação) - Instituto de Biociências, Universidade Estadual Paulista, Rio Claro, São Paulo.

VIANNA, H. M. Pesquisa em Educação: a observação. Brasília: Líber Livro Editora, 2007. 108p.

VIAL, M., CAPARROS-MENCACCI, N. L'accompagnement professionnel ?Méthode à l'usage des praticiens exerçant une fonction éducative. De Boeck Supérieur, «Pédagogies en développement », $2007,340 \mathrm{p}$.

VILLENEUVE, L. ; MOREAU, J. Former des superviseurs et des maitres de stage. In : RAUCENT, B et al. Accompagner des étudiants. Bruxelas, Bélgica : De Boeck Supérieur, 2010 pp. 443-470. Disponível em: < https://www.cairn.info/accompagner-des-etudiants--9782804133313-page443.htm\#>. Acesso em: 13 out. 2014.

WEISSER, M. Dispositif pédagogique? Dispositif didactique? Situation d'apprentissage! Questions vives, recherches en éducation, vol. 4, n¹3, 2010. Disponível em:.

http://questionsvives.revues.org/271. Acesso em: 10 out. 2012.

ZABALZA, M. O estágio e as práticas em contextos profissionais na formação universitária. São Paulo: Cortez, 2014.

Submetido: $15 / 09 / 2019$

Aprovado: 08/08/2020 